\title{
THE PROBLEM OF KLAIPĖDA REGION PERIPHERALITY
}

\author{
Gintaré Pociūté ${ }^{1}$
}

Institute of geology and geography (Lithuania)

\begin{abstract}
This article presents the socioeconomic and demographic situation in Klaipeda county that is illustrated by chosen indicators' analysis. In this article Klaipedda county has been chosen as an example territory to measure the peripherality phenomenon. Thus, in order to measure the peripherality the chosen indicators' values were compared with Lithuanian average and state's centres' values. The article stresses the most peripheral regions in Klaipeda county which needs the governance attention and also the strongest one that leads all the county. The article finds out that the cooperation question is essential for both - county's peripheries and centres - as it provides possibility to stay stable or even endows a potential to grow.

KEY WORDS: Klaipeda county, core-periphery, peripheral region, cooperation.
\end{abstract}

\section{JEL CODES: R100}

\section{Introduction}

The peripherality question is one of the most essential ones' while discussing about the region's possibility to compete and at the same time cooperate with other regions. In the cooperation sphere the priority is usually given to the stronger and more centrality features worth regions as these regions have enough of social, economical, demographical stock.

In this case appears the question: which regions might me noticed as central ones and which ones should be underlined as peripheral? Thus, this article takes a task to clarify this question while taking Klaipéda region as an example for measuring peripherality of this specific region. In this article the peripherality phenomenon is going to be declared via chosen socioeconomic and demographic indicators provided by Department of Statistics of Lithuania.

The general purpose of the article is with the help of the most relevant up to date statistical data (that include the most essential according to the author social, economic, and demographic indicators) to underline the current situation of Klaipeda region. In this way the article seeks for the answer if Klaipeda region should be declared as central region in Lithuania that has enough potency for the domestic and international cooperation or still this region should be considered as peripheral one. In order to clarify the region's position, it is necessary Klaipeda region's statistical findings compare with Lithuanian average data. Also, in the research it is imposed Vilnius city and Kaunas city municipalities' statistical data as these two largest country's cities are considered as Lithuanian centres. Thus, in the peripherality research it is informative material in order to notice the difference.

Generally, peripherality question is being analyzed by broad amount scientists taking into account geographers, sociologists, economists and others (Krugman, Venables, 1995; Schmidt, 1998; Knox, Marston, 2001; Jerabek, 2006; Daugirdas, Burneika, 2006; Marada, Chromy ir kt., 2006; Nagy, 2006, Pociūtè, 2011). Summarizing scientists' proposed definitions and this article author's ideas, peripheral region might be un-

\footnotetext{
Gintare Pociūtė - Nature research centre, Institute of geology and geography, Laboratory of Human Geography, PhD student. Scientific interests: peripheral regions in Lithuania, regional geography, regional policy, territorial polarization.

E-mail: Gintarei.pociutei@gmail.com

Tel.: +370 60771137
} 
derstood as the territorial unit, located outside the centre boundary, and related with the centre on the dependence link, characterized by the lagging behind from the average and lowest geographic, socioeconomic, demographic, cultural, and political indicators. However, the research in this article excludes some of the aspects proposed in the definition and takes into account several socio-economic and demographic indicators.

Peripherality is closely linked to centrality researches as these are the two poles of the dichotomy model. Therefore, working on peripherality evaluation researches it is important to understand how the core-periphery (CP) model works because this model allows to understand the place of the periphery in the territory system and at the same time points out the periphery relations with other unites of this system (Fig. 1). The idea of CP model appeared in the middle of XX century and firstly was produced by J. Friedmann (Friedmann, 1966) and it should be stressed that the model was modified since its first idea. Nowadays scientists introduce other territorial unites in between of centre and periphery poles. For instance, Z. Norkus (Norkus, 2009) gives an idea that the territorial disparities' model should have four levels (Fig. 1). The author underlines that the strongest regions should be called centres that are usually surrounded by peripheries. Thus Z. Norkus defines these territories around centres as centre-peripheries. According to author, the weakest regions in the country are pointed out as peripheries. But at the same time, these weakest regions have the local centres that are more developed territories in the regions. Accordingly, these better developed territories in peripheral region are named periphery-centres (Fig. 1).

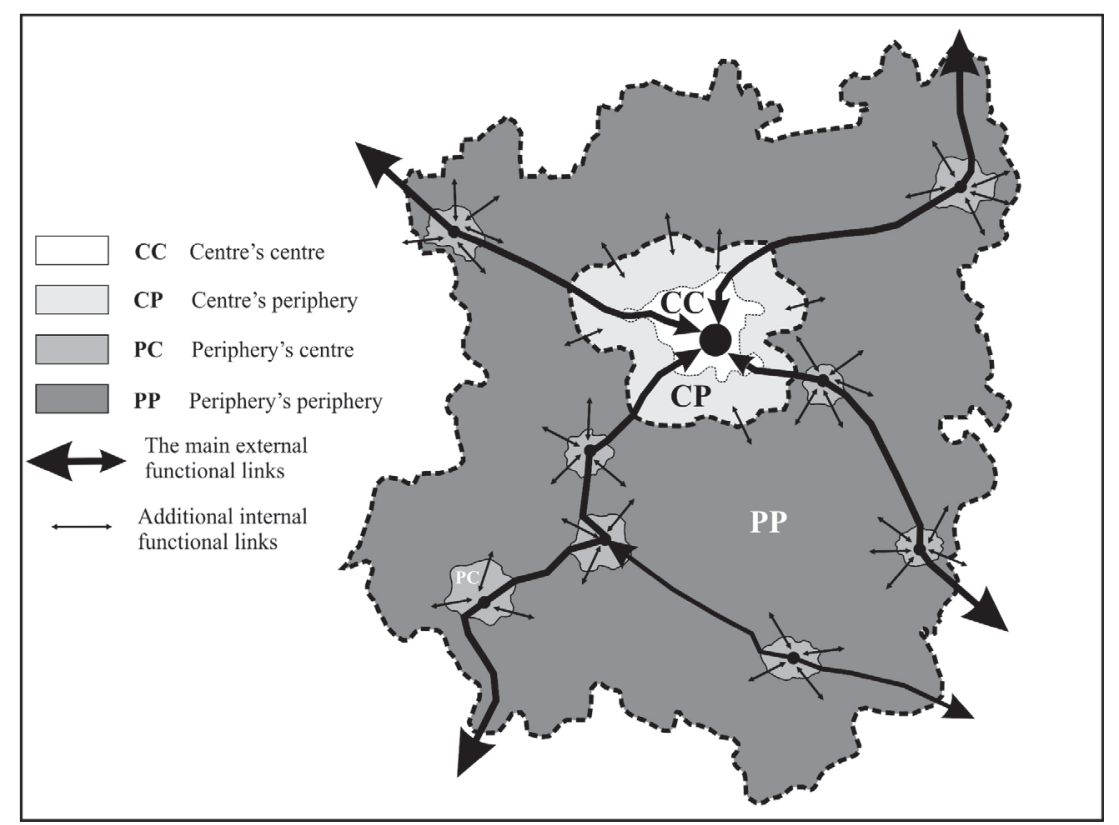

Figure 1. Centre-periphery model (according to Z. Norkus idea) Source: Norkus, 2009

The model that is developed using Z. Norkus (Norkus, 2009) idea might be adapted for Klaipeda region as this region is particularly diverse. Klaipeda county has strong centre which is Klaipeda city with the national level seaport. Also this county has deep peripheral territories that are mostly located in country's border zones. Furthermore, Klaipeda region has centre-peripheries and periphery-centres in between. Thus, one of this article goals' is to underline the differences in this particular Klaipeda county. The portrait of the current situation in Klaipeda region would allow to take specific measures in order to improve the conditions for national and international cooperation.

As the one of the purposes' of this article is to compare chosen for the survey territories with the Lithuanian average, the methodology for this survey has been chosen in this way:

- for the selected socioeconomic indicators' analysis: the Lithuanian average (LT average) is equated to $100 \%$, thus this allows to see the regions deviation (negative or positive) from the LT average value; 
- selected demographic indicators' analysis is prepared comparing general statistical data of chosen regions with Lithuanian average values. The percentage comparison is not applied to demographic indicators due to appearing logic mistakes influenced by sufficiently big differences between values.

\section{The general picture of Klaipeda county}

The first thing that has to be mentioned while talking about Klaipeda county is this region's special geographical position that makes this county unique in Lithuania. The region is situated in Western Lithuania on the coast of Baltic sea and is an important district in terms of marine business, recreation and tourism, industry and agriculture as well. The county borders with two countries - Latvia and Kaliningrad region (Russian Federation). Moreover, Klaipeda county might be interesting for other countries to cooperate as it has such strategic objects like Palanga Airport and especially Klaipeda State Seaport which is the only sea gate in Lithuania (Portrait of..., 2008). Thus, geographic location makes Klaipeda county favourable for developing international cooperation relations.

Table 1. The comparison of Klaipeda county with Lithuanian average Vilnius, Kaunas and Klaipèda cities statistical data

\begin{tabular}{|c|c|c|c|c|c|c|c|c|c|c|c|c|c|}
\hline & \multicolumn{13}{|c|}{ INDICATORS } \\
\hline & 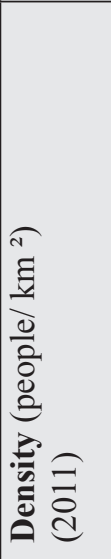 & 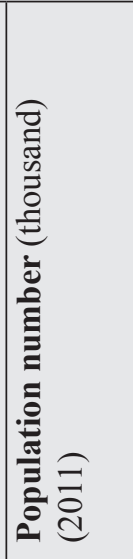 & 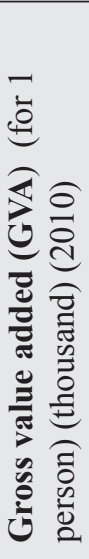 & 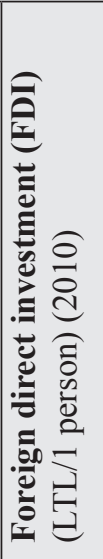 & 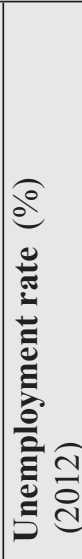 & 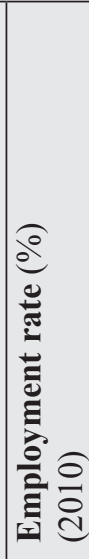 & 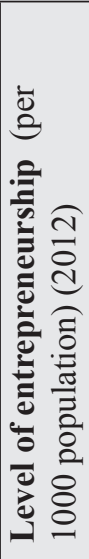 & 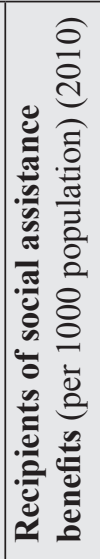 & 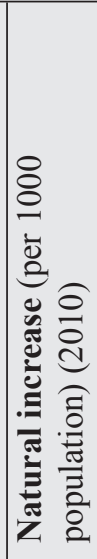 & 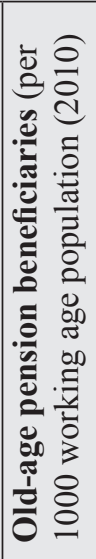 & 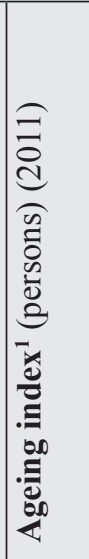 & 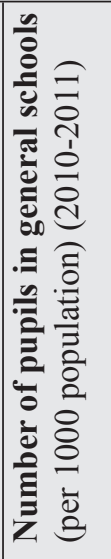 & 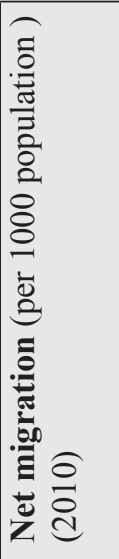 \\
\hline LT average & 49.7 & $3244.6^{3}$ & 25.8 & 10958 & 11.0 & 58.5 & 20.5 & 55.9 & -2 & 283 & 144 & 128.2 & -24.0 \\
\hline Vilnius city & 1381.7 & 554.1 & 37.7 & 37831 & 9.3 & 69.4 & 39.4 & 19.2 & 3.5 & 251 & 132 & 121.4 & -14.6 \\
\hline Kaunas city & 2145.9 & 336.9 & 28.1 & 10003 & 9.8 & 63.8 & 29.1 & 30.6 & -0.4 & 287 & 157 & 130.8 & -34.4 \\
\hline $\begin{array}{l}\text { Klaipéda } \\
\text { city }\end{array}$ & 1814.4 & 177.8 & 32.3 & 13309 & 8.6 & 65.4 & 29.1 & 30.7 & 0.8 & 261 & 143 & 119.3 & -28.6 \\
\hline $\begin{array}{l}\text { Klaipéda } \\
\text { county }\end{array}$ & 70.4 & 366.9 & 26.7 & 9128 & 9.9 & 59.9 & 22.9 & 44.5 & -0.3 & 262 & 134 & 124.0 & -26.0 \\
\hline
\end{tabular}

Source: Lithuanian Labour Exchange, Counties of Lithuania 2010, Statistical Yearbook of Lithuania 2011, Economic and Social Development in Lithuania2011/12, Demographic Yearbook 2010

In order to attract the attention of neighbour countries and encourage the border cooperation the region should be attractive not only by geographic factor but also by socioeconomic and demographic aspects. Thus, the current situation of Klaipeda county is presented in Table 1. Also, the table presents information that concerns Vilnius, Kaunas and Klaipeda cities and Lithuanian average data. Therefore, the statistical data in the table allow to compare Klaipeda city and county with Lithuanian centres and state's average and

2 Ageing index: the number of elderly people (aged 60 and over) per 100 children under 15 (Department of Statistics of Lithuania: http://zodynas.stat.gov.lt/index/detail.aspx?id=73)

3 Total number of residents' in Lithuania. 
in this way it is possible to notice if Western Lithuanian region appears peripheral or central in Lithuanian context. However, it should be stressed that while presenting the statistical data we still have to understand that positive numbers do not mean that the situation in the region is perfect as there might be hidden factors that could strain the real region's situation. For instance, it might be noticed the growing numbers of foreign direct investment for a person but at the same time it might be admitted that these numbers are growing influenced by the decreasing county's inhabitants' number. Thus, one statistical data should supplement other and the overview of the situation in the region should be based on interpretations of taking into account the group of various indicators.

The article is based on researches of peripherality, thus, the indicators were selected in order to measure this phenomenon. Meanwhile peripherality is being understood as the deviation from the average towards negative side, in order to notice if Klaipeda might be called as peripheral region there is the need to compare the regions' statistical data with Lithuanian average (Fig. 1).

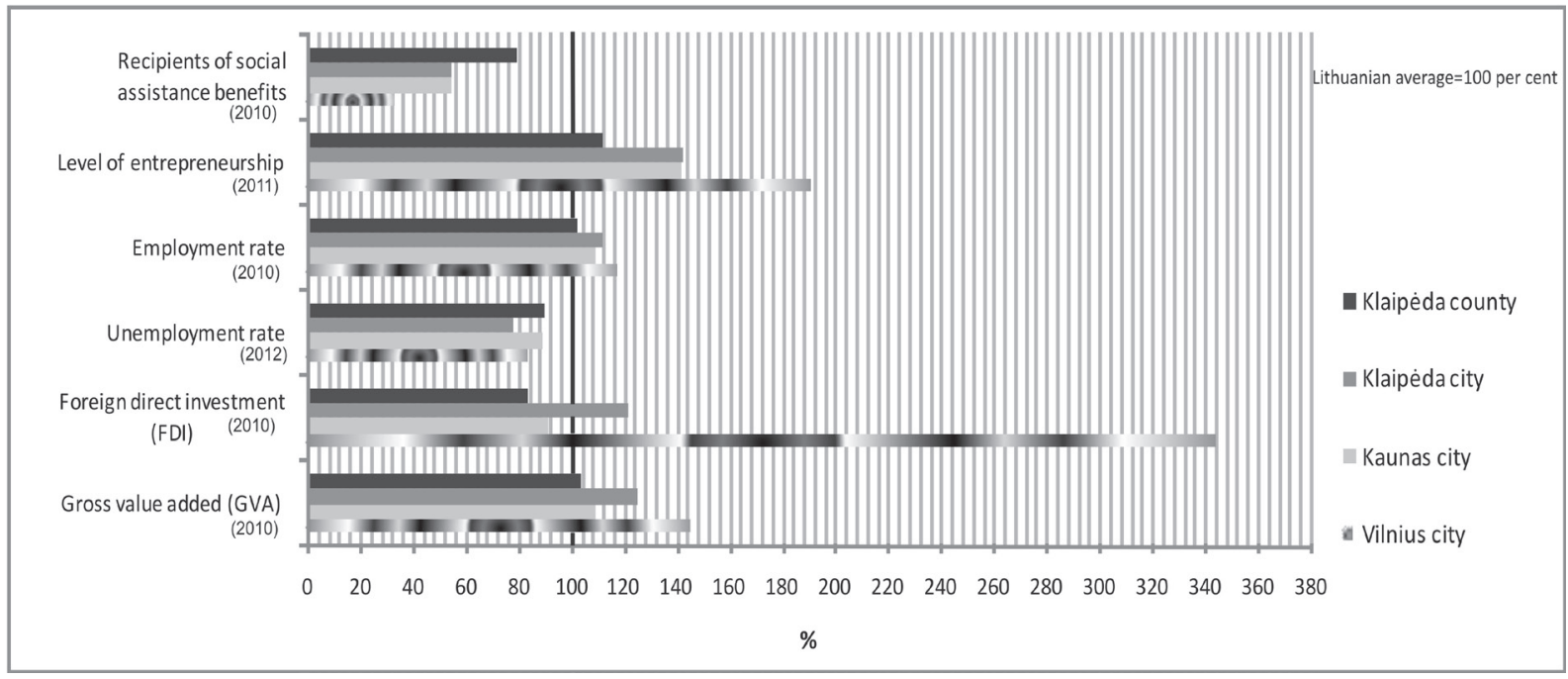

Figure 2. The comparison of socioeconomic indicators between

Klaipeda, Vilnius and Kaunas cities, Klaipėda county municipalities' and Lithuanian average

Source: Lithuanian Labour Exchange, Counties of Lithuania, 2010; Statistical Yearbook of Lithuania, 2011; Economic and Social Development in Lithuania, 2011/12; Demographic Yearbook, 2010

As the figure shows, it obvious that the best rate of socioeconomic indicators' values are in Vilnius city municipality. These findings should not astonish because Vilnius city as the Lithuanian centre attracts much more attention. As well, being political, economical, social centre Vilnius is interesting for international companies. Thus, the foreign direct investment in Vilnius city is more than 3 times bigger comparing with Lithuanian average. Besides, Vilnius city municipality interfere less with such social problems as employment rate which is $20 \%$ higher in comparison with LT average (Fig. 2). Also, Vilnius city municipality strongly leads in the comparisons of level of entrepreneurship that is more than $90 \%$ higher than LT average (Fig. 2). It is obvious that Vilnius city municipality takes all the advantage in this socioeconomic comparison and reflects relevantly big disparities within Lithuania. Thus, there might be ideas that while looking for peripherality in Lithuania Vilnius city municipality should be eliminated. However, on the other hand, keeping Vilnius city municipality in the research is the way to show the distance from centre to the periphery region.

In this comparison work Kaunas city municipality stands in the third position. Though, it should be stressed that with its socioeconomic indicators' values are more common to Klaipeda city than to Vilnius city.

In this paper work the biggest attitude should be paid to Klaipeda city and county. Thus, it should be noticed that the most recently presented statistical data show that in general Klaipeda county goes around Lithuanian average and lags behind Vilnius city municipality according to the chosen for the survey indicators' 
values. However, the statistical data that present Klaipeda city are much more higher than Klaipeda county's data. Klaipeda city taking into account its statistical information stands in the second position overtaking Kaunas city and standing behind Vilnius. Klaipeda city municipality is the strong centre in Klaipeda county (according to the model in Fig. 1: "Centre's centre") that pulls ahead all the region. But these differences within the county would be unravelled in another article's section.

$27.5 \%$ of all Klaipeda county residents' are living in rural area and it is around $20 \%$ less comparing with Lithuanian average (Fig. 2). Unemployment rate in the county is $10 \%$ less in comparison with average. Meanwhile in Klaipeda city this indicator is more than $20 \%$ less than LT average. Klaipeda county (11\% higher than LT average) and Kalipeda city ( $42 \%$ higher than LT average) have better indicators' values if talking about the level of entrepreneurship. Moreover, in Klaipeda region the number of recipients of social assistance is around $20 \%$ lower than LT average and in Klaipeda city even $45 \%$ lower. While talking about foreign direct investment (FDI) it should be underlined that Klaipeda county receives around $15 \%$ less comparing with LT average (Fig. 2). But if taking only Klaipeda city, the FDI indicator is relatively high (25.2\% higher than LT average). According to this indicator Klaipeda city oversteps Kaunas city and is competing with Vilnius city.

Taking into account demographic indicators it might be also noticed the differences between these chosen for the survey Vilnius, Kaunas and Klaipeda cities, Klaipedda county and Lithuanian average (Fig. 3). Generally, the statistical data that provide the view of current demographic situation in Vilnius, Kaunas and Klaipeda cities, Klaipeda county or present the Lithuanian average are threatening. According to up to date numbers, natural increase (except Vilnius and Klaipeda cities) and net migration indexes that are counted for 1000 inhabitants are negative. As well, ageing index stresses the growing problematic situation while showing that there are more elderly people aged 60 and over than children under 15 . This ageing problem is underlined by old-age pension beneficiaries and number of pupils in general schools indicators (Fig. 3).

The best demographic situation as well as the socioeconomic is in Vilnius city municipality and this is directly connected with state capital status. The positive natural increase is detected only in Vilnius city which reaches $3.5 \%$ and Klaipeda city with $0.8 \%$ while the LT average is $-2 \%$. Whereas, in Klaipeda county and Kaunas city the natural increase is higher more than 5 times comparing with Lithuanian average and reaches $-0.3 \%$ in Klaipeda county and in Kaunas $-0.4 \%$.

Nowadays the migration topic is quite common. This problematic topic is exceptional because of the growing emigration numbers. The statistical data showing the portrait of current Lithuanian migration situation are daunting. In 2010 the LT net migration average was $-24 \%$. In Klaipeda county this number reached $-25 \%$ while in Klaipeda city even more bigger counting - $28,6 \%$. The worst numbers were detected in Kaunas city - reaching - $34 \%$. Only in Vilnius city the net migration indicator's value was better than LT average but still negative $-14.6 \%$ (Fig. 3).

As it was already mentioned, the indicators are closely connected to each other. Therefore, the natural increase or net migration indicators' values has an influence on ageing index, old-age pension beneficiaries or number of pupils in general schools indicators' values. This connection might be disclosed by noticing that usually emigration is based on younger generation. Thus, the consequences might be seen in decreasing number of population. Moreover, the growing emigration and decreasing population amount increases the progressing number of elderly people and decreasing number of pupils at schools. The biggest problems appear when there is imbalance in the society: too many old people, too little children and not enough working people (tax payers).

Lithuanian average ageing index is 144 . Therefore, it means that for 100 children under 15 falls 144 elders. There are almost half more old-aged people comparing with children. The ageing index in comparison with LT average is lower in Vilnius city municipality (reaching 132), Klaipeda county (counting 134) and Klaipeda city (counting 143). Whereas in Kaunas city the aging index is higher and reaches 157. 


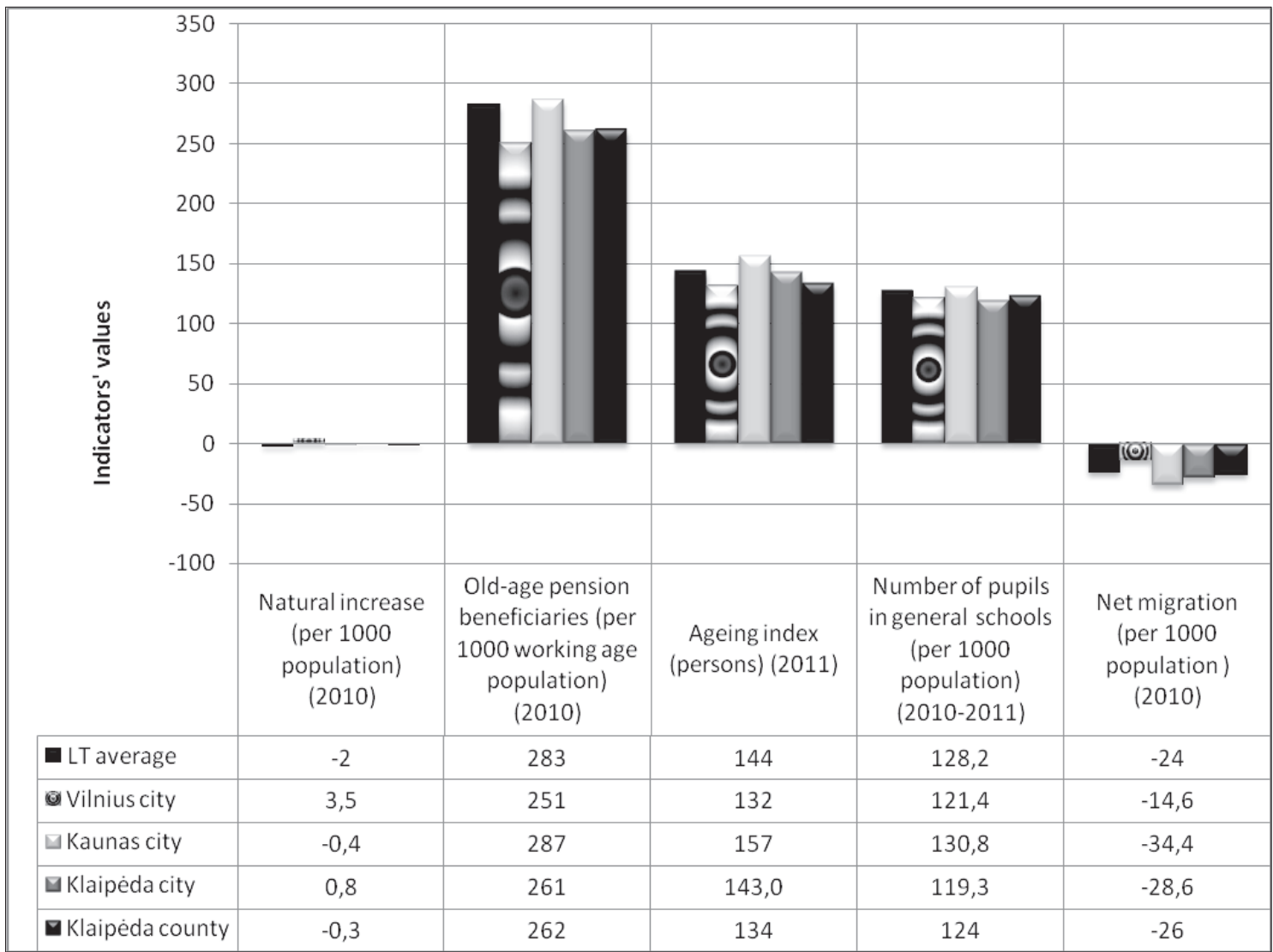

Figure 3. The comparison of demographic indicators between Klaipėda county, Vilnius and Kaunas cities municipalities' and Lithuanian average

Source: Lithuanian Labour Exchange, Counties of Lithuania, 2010; Statistical Yearbook of Lithuania, 2011; Economic and Social Development in Lithuania, 2011/12; Demographic Yearbook, 2010

\section{The disparities within Klaipeda county}

While the general picture of Klaipeda county looks pretty good in the Lithuanian context with mostly all the indicators' numbers above the state's average, the disparity's question within Klaipeda county is much more problematic. In this county might be underlined the districts with one of the worst rates' in Lithuania (for example, Skuodas district, which according to model in Fig. 1 might be equalled to "Periphery's periphery" term) and at the same time with one of the best state's rates' (for instance, Klaipeda city municipality - "Centre's centre") (Mano finansai..., 2012). Therefore, analyzing these Klaipeda county's districts separately would benefit in stressing the most sensible regions within this county. As well, the districts of the county are compared with Lithuanian average in order to estimate the peripherality level (Fig. 4; 5).

It is essential to stress that Klaipeda city, Neringa and Palanga municipalities are the territories that differ from other this county's districts as these three municipalities are urban taking into account the lifestyle while other county's districts that are rural in there way of life. As well, Klaipeda city, Neringa and Palanga municipalities are the resorts that during the summertime attract a lot of holidaymakers. Moreover, Neringa municipality is the most exceptional in Klaipeda county according to the statistical data. The values of indicators presenting Neringa municipality are relatively high comparing not only with Klaipeda county districts but also with Lithuanian average or state's centres. However, it does not mean that Neringa municipality does not face with any problems and the living situation is the most favourable in all the Klaipeda county or even state. Probably it is even right to declare that the current statistical data does not reflect the real situation 
in this municipality. The situation in Neringa municipality is strained because of the economic profit while wealthy residents from other Lithuanian regions buy or invest in real estate in Neringa without a will to live there but only keep there estate as the summer houses. Such people register as Neringa municipality residents in order to get discounts while taking ferry or avoid the municipality entrance fee. On the other hand, taking into consideration the border cooperation Neringa municipality is open minded, interesting, active and attractive for investors, thus perfectly suitable for cooperation.

Taking into account the cooperation question one of the possibilities to reveal the region's potential might be pointing out the level of entrepreneurship. This indicator underlines the residents' activity level and susceptibility for development. Thus, the level of entrepreneurship is higher in the centres where residents usually seek for innovation. Meanwhile the rural or peripheral regions lack behind according to this indicator because these regions are more traditional and more passive for the novelty. Besides, the low level of entrepreneurship might be also determined by demographic indicators as when the population number is low and even decreasing there is no need to establish new enterprises. Therefore, the highest level of entrepreneurship in Klaipeda county might be noticed in Klaipeda city ( $42 \%$ higher than average), Neringa ( $86.3 \%$ higher than average) and Palanga (56.6\% higher than average) municipalities (Fig. 4). While the lowest level of entrepreneurship is detected in Skuodas (56.6 \% less than LT average) and Šilute (36.1 \% less) districts (Fig. 4).

Gross value added (GVA) created by municipalities in Klaipeda county are relatively low comparing with LT average. Only Klaipeda city's GVA is $25.2 \%$ higher that Lithuanian average. The other districts have lower GVA that state's average. The lowest GVA in 2010 was detected in Neringa (31.8\% lower than average), Palanga (31 \% lower) and Skuodas district (30.6 \% lower) municipalities (Fig. 4).

The highest unemployment rate in Klaipeda county is detected in Skuodas district (33.6\% higher than LT average), Palanga city (27.3\% higher) and Šilute district (20\% higher). While the best situation is in Neringa municipality ( $60 \%$ below LT average) and Klaipeda city ( $21.8 \%$ below average). One of the reasons why the situation in this case in Neringa is the best is because of the registered people who mostly exist in statistical papers but actually work and live in Vilnius, Kaunas or other places. Meanwhile, V. Borteliene (Bortelienè, 2012) prepared a research about Klaipedda city where she stresses that still existing positive numbers of current situation in Klaipeda city hide escalating problems. Currently unemployment rate in Klaipéda city in general number is $8.6 \%$ which is above state's average and one of the highest in the county. But as the author points out, this indicator in Klaipeda city is growing not because of stable economy but mostly because of the terrifically vanishing the number of registered resident's. Therefore, high numbers of employment rate might be an alert of emigration.

The best employment rate is counted again in Klaipeda city that is $11.8 \%$ above LT average. It has to be noticed that this is the only municipality in this county that is above LT average. According to this indicator Neringa municipality stays behind other Klaipeda county's districts and is $20.7 \%$ lower than Lithuanian average. This huge difference appears because most Neringa municipality residents' own their business and work only during the summer time earning money for the rest of the year. The similar situation is with Palanga municipality that is lagging lacing $12.3 \%$ behind LT average.

In 2010 the biggest amount of foreign direct investment (FDI) lied in Klaipeda district and counted $28.2 \%$ higher than LT average. As well $21.5 \%$ higher than average FDI got Klaipeda city. Whereas, Skuodas and Šilute districts seem to be less interesting for investors and were more than $90 \%$ below LT average according to FDI indicator (Fig. 4).

Statistical data show that Skuodas and Šilute districts have the biggest amount recipients of social assistance benefits. According to this indicator Skuodas district oversteps LT average by $33.5 \%$ and Šilute district by $38.5 \%$. This indicator underlines the residents' humble life conditions and problematic social situation. The minimal number ( $84.8 \%$ less than LT average) of recipients of social assistance benefits is detected in Neringa municipality. This indicator and its value has direct link to unemployment rate and that is obviously noticed in the Fig. 4. 


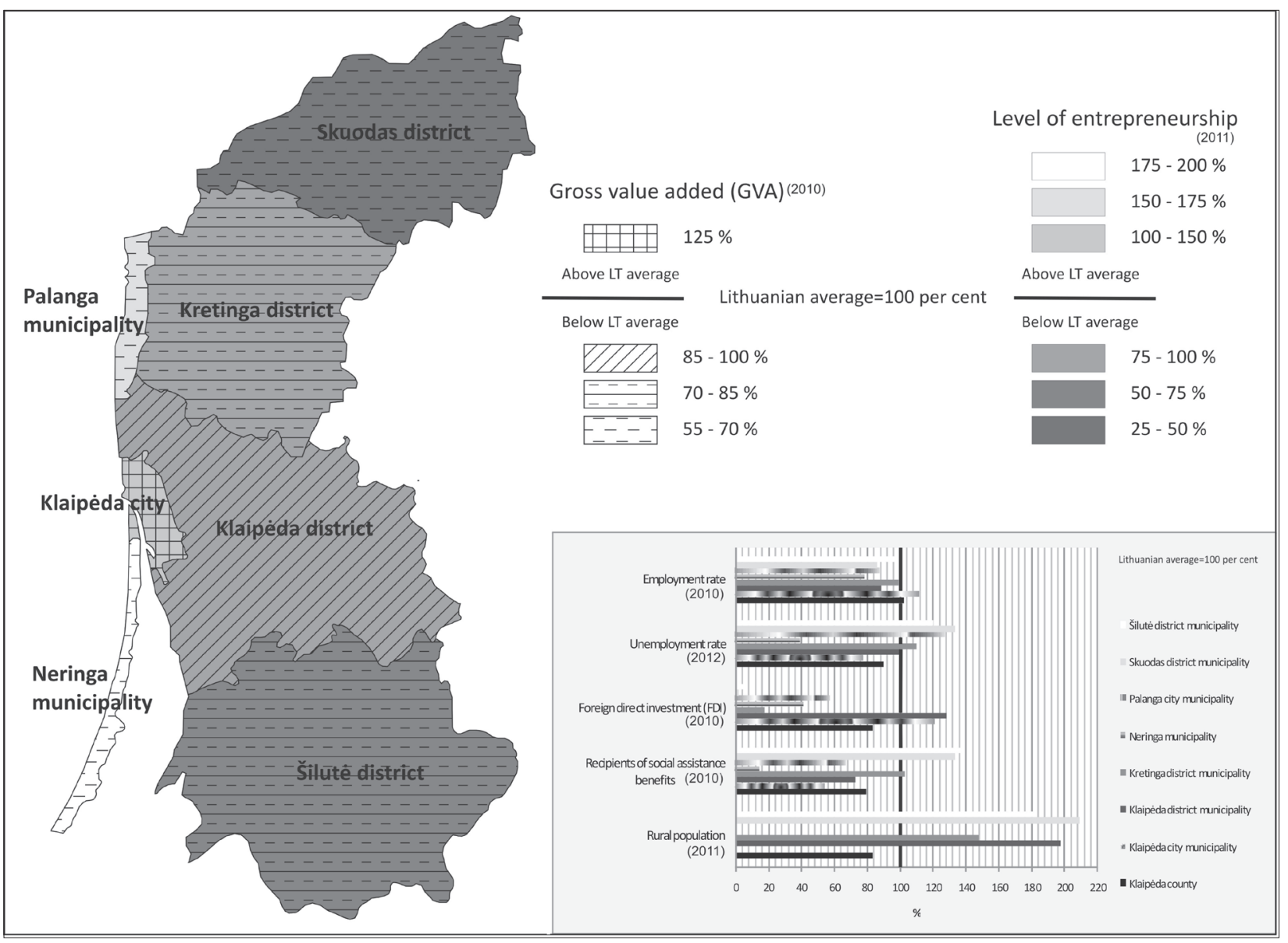

Figure 4. The comparison of socioeconomic indicators within Klaipèda county

Source: Lithuanian Labour Exchange, Counties of Lithuania, 2010; Statistical Yearbook of Lithuania, 2011; Economic and Social Development in Lithuania, 2011/12; Demographic Yearbook, 2010

In Klaipeda county the most rural district is considered to be Skuodas district which oversteps LT average twice thus it is counted that the rural population in this district is $109.1 \%$ higher than LT average.

The demographic situation within Klaipeda county is also controversial enough. There are huge differences in the municipalities while comparing indicators' values (Fig. 5).

If the Lithuanian average talking about natural increase indicator is -2.0 per 1000 population, in Neringa this indicator is positive and counts 3.2 per 1000 population. Positive natural increase is also in Klaipeda city (0.8) and Klaipeda district (1.6). While the lowest natural increase level is detected in Skuodas district and reaches even -6.5 per 1000 population (Fig. 5).

Net migration indicator is the lowest in Šilute municipality and counts -42.7 per 1000 population while LT average is -24.0 per 1000 population. The negative numbers declare unfavourable conditions for living and working. Meanwhile Neringa municipality counts positive migration net which reaches 40.0 per 1000 population. As it was mentioned, this high number is influenced by registered in this municipality but not constantly living but owning real estate residents. Above the LT average is also Klaipeda district municipality which counts -10.9 per 1000 population. According to V. Bortelienè (Bortelienè, 2012) Klaipéda district municipality gets the higher values as this municipality receives more and more residents from Klaipeda city. Previous Klaipeda city's residents chose the comfortable life out of the city in growing new settlements in Klaipeda district municipality. This migration from Klaipeda city to the district appears a problem for the city municipality as the residents leaving city leave blank houses of flats. Moreover, the taxes that were paid by them to the city are now directed to the district municipality. 


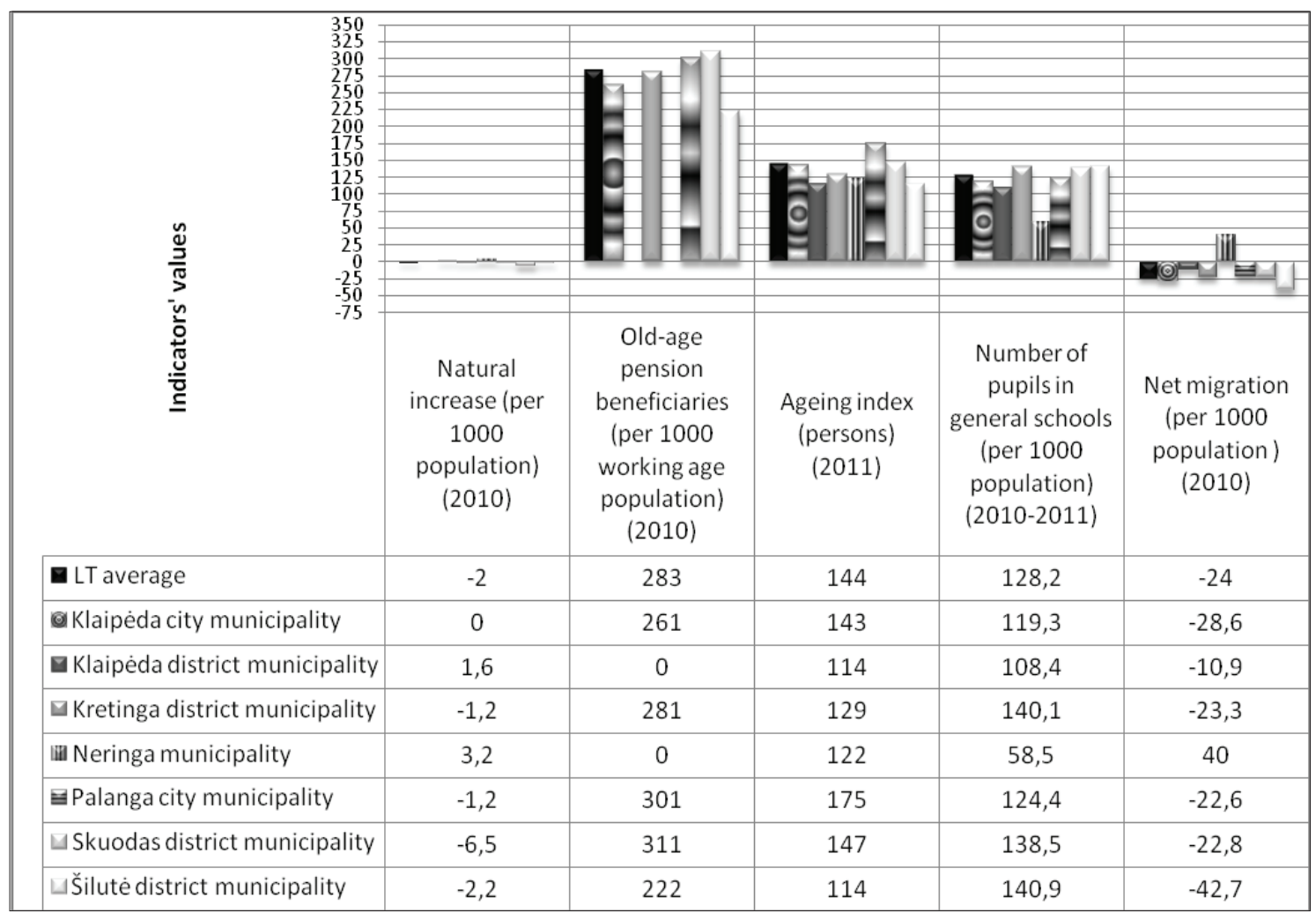

Figure 5. The comparison of demographic indicators within Klaipėda county

Source: Lithuanian Labour Exchange, Counties of Lithuania, 2010; Statistical Yearbook of Lithuania, 2011; Economic and Social Development in Lithuania, 2011/12; Demographic Yearbook, 2010

The ageing index declares the existing problem of growing number of elderly people but this is the problem relevant not only in this county but also in all the state, thus seeking for the solution should be based on state governance. The average ageing index in Lithuania is 144.0. The worst situation according to this indicator in all Klaipeda county is noticed in Palanga municipality ( 175.0 per 1000 working age population) where old-age people are almost twice more than young or working residents (Fig. 5). As well, this index is high in Skuodas district (147.0 per 1000 working age population). The best situation is in Klaipeda district (114.0 per 1000 working age population) that is also connected with the immigration from the city and in Šilute district (114.0 per 1000 working age population) which has high enough young children number (Fig. 5). Šilute district has one of the lowest old-aged pension beneficiaries' number's (222.0 per 1000 working age population) one of the highest counting the number of pupils in general schools (140.9 per 1000 population). According to old-age pension beneficiaries indicator, Skuodas district has the worst position in the county reaching 311.0 per 1000 working age population while the LT average is 283.0 per 1000 working age population (Fig. 5).

Taking into account the demographic Klaipeda county situation it seems that the worst situation is in border districts - Skuodas and Šilute. Considering that the indicators underline peripherality, Skuodas and Šilute districts would be noticed as peripheral regions in Klaipeda county.

\section{Conclusions}

Klaipeda county is relatively strong in Lithuanian context and according to the indicators chosen for the survey is most of the time above LT average and can compete with Lithuanian centres. Therefore, in general Klaipeda county can not be called peripheral region. However, despite the fact that Klaipeda county is one of the strongest ones in Lithuania, the differences within this county are big enough. The worst situation 
and biggest deviation from Lithuanian average values are in Skuodas and Šilute districts while the best indicators' values are detected in Klaipeda city, Neringa and Palanga municipalities. Therefore, applying the CP model to Klaipeda county taking into account data provided by Department of Statistics of Lithuania, Klaipeda city, Neringa and Palanga municipalities would be seen as "Centre's centres", whereas Skuodas and Šilute districts would reflect another model's pole which is "Periphery's periphery". These differences are mostly influenced by geographical location (border phenomenon) and strategically beneficial position (resorts, state sea port).

It is essential to underline that it is not possible to evaluate objectively only via statistical data the region's peripherality and potential for cooperation. The statistics just gives the general view of the territory, whereas there are subjective features influenced by cultural, historical conditions or mental apprehension which should be also taken into account.

There is no question if this Western Lithuanian region should cooperate with neighbour countries. The question is how the border-cooperation should be developed in order to benefit for all the cooperating countries and at the same time solving the rising problems of Klaipeda region. Should the cooperation be implemented only via centres while leaving aside the weakest county's regions? Or if we are talking about border-cooperation should the most serious action be taken in border regions in this case the peripheral regions excluding the centres? There are several scenarios how the border-cooperation might be realised and up to the county and district's governance decide the most suitable way.

\section{References}

Counties of Lithuania 2010. (2011). Lietuvos statistikos departamentas. Vilnius.

Daugirdas, V., Burneika, D. (2006). Patterns and problems of peripheriality in Lithuania - borderland of the EU. Europa XXI. Regional periphery in Central and Eastern Europe, Vol. 15, p. 119-133.

Demographic Yearbook 2010. (2011). Lietuvos statistikos departamentas. Vilnius.

Economic and Social Development in Lithuania2011/12. (2012). Lietuvos statistikos departamentas. Vilnius.

Friedman, J. (1966). Regional development policy: a case study of Venezuela. Cambridge: MIT Press, 279 p.

Jerabek, M. (2006). Research into peripheral areas in the Czech Republic - changes in the landscape and land use in the model regions, Europa XXI. Regional periphery in Central and Eastern Europe, Vol. 15, p. 171-183.

Knox, P. L., Marston, S. A. (2001). Places and Regions in Global Context. Human Geography. Prentice Hall: New Jersey, $526 \mathrm{p}$.

Krugman, P., Venables A. (1995). Globalization and the Inequality of Nations, Quarterly Journal of Economics, Vol. 60, p. $857-880$.

Marada, M., Chromy, P. ir kt. (2006). Space polarisation and peripheral regions in Czechia. Europa XXI. Regional periphery in Central and Eastern Europe, Vol. 15, p. 29-34.

Norkus, Z. (2009). Nepasiskelbusioji imperija. Vilnius: Aidai, 476 p.

Pociūtė G. (2011). Periferinio regiono sampratos problema Lietuvoje. Annales Geographicae, Vol. 43-44(1-2), p. 128-143.

Portrait of the regions of Lithuania. (2006). Lietuvos statistikos departamentas. Vilnius, $154 \mathrm{p}$.

Schmidt, M. H. (1998). An integrated systemic approach to marginal regions: from definition to development policy. Ed. Jussila et al. Perceptions of marginality: theoretical issues and regional perceptions of marginality in geographic space, p. 45-66.

Statistical Yearbook of Lithuania. (2011). Lietuvos statistikos departamentas. Vilnius.

\section{Websites}

Bortelienė, V. Klaipeda nyksta ir skursta. Lietuvos žinios. http://www.lzinios.lt/Ekonomika/Klaipeda-nyksta-ir-skursta (žiūrèta 201201 27).

Department of statistics of Lithuania. http://www.stat.gov.lt/en/pages/view/?id=1350 (žiūrèta 20120125 ).

Lithuanian labour exchange. http://www.stat.gov.lt/en/pages/view/?id=1350 (žiūrèta 201201 27).

Mano finansai. „Swedbank“ Asmeninių finansų instituto buveinè internete https://www.manofinansai.lt/lt/menesio-tema/240/finansines-situacijos-zemelapis-arba-kodel-lietuvai-gresia-rygos-sindromas (žiūrèta 201201 25). 


\section{KLAIPEDOS REGIONO PERIFERIŠKUMO PROBLEMA}

Gintarè Pociūté

Geologijos ir geografijos institutas (Lietuva)

\section{Santrauka}

Iprasta, kad didesnio dėmesio, investicijų, projektų ar bendradarbiavimo pasiūlymų susilaukia regionai, turintys gerą ekonomini, socialini, demografini, geografini ar kitokị ịvaizdị. Dažniausiai patrauklios tampa centrų vaidmeni atliekančios vietovès, tuo tarpu periferiniai regionai nustumiami i šalị. Tačiau egzistuoja dilema, kurios teritorijos įvardijamos kaip centrai, o kurios - kaip periferija? Atsakymas ị ši klausimą yra vienas šio straipsnio uždavinių.

Periferiškumo fenomenui analizuoti autore pasirinko keletą socioekonominių ir demografinių rodiklių, kurie, autorès nuomone, geriausiai identifikuoja teritorinius netolygumus atitinkamais aspektais. Svarbu pabrèžti, kad šiame darbe periferiškumas suvokiamas kaip neigiamas nuokrypis nuo vidurkinių reikšmių: taigi, kuo didesnis neigiamas nuokrypis nuo vidurkio, tuo didesnis periferiškumo laipsnis. Svarbu pastebèti ir tai, kad šiame darbe pateikiamas tik statistinis periferiškumo nustatymas, tuo tarpu visapusiškam periferiškumui nustatyti reiketų remtis ir subjektyvumo turinčiais tyrimais: psichologinio suvokimo, istorinių ar kultūriniu elementu itakos visuomenès nuomonei analize.

Straipsnyje analizuojama Klaipėdos apskritis, kuri ganètinai įdomi dẻl savo i̇vairumo: čia veikia tiek valstybės lygmens centras, kuris aukštais socioekonominiais ir demografiniais rodikliais išsiskiria iš likusiu apskrities savivaldybių, kartu ji yra viena silpniausių ir periferiškiausių savivaldybių valstybės lygmenyje. Šie skirtumai dažniausiai nulemti geografinès padèties: visoje Lietuvoje egzistuoja tendencija, kad pasienio regionai atsiduria periferinèje zonoje.

Klaipeddos regiono periferiškumo klausimas analizuojamas lyginant šio regiono duomenis su Lietuvos vidurkinėmis reikšmėmis ir didžiaisiais Lietuvos miestais - Vilniumi ir Kaunu, kurie valstybès lygmenyje atlieka centrų funkcijas. Gauti duomenys parodè, kad visų rodiklių aukščiausios reikšmės aptinkamos politinèje, ekonominëje, socialinèje bei geografinèje sostinèje - Vilniaus mieste. Tuo tarpu Klaipėdos miestas, nors ir atsilieka nuo Vilniaus rodikliu, pralenkia Kauną ir pasižymi puikiais statistiniais rezultatais. Klaipèdos miestas, remiantis statistiniais rodikliais, gali būti įvardytas kaip strategiškai svarbus centras ne tik Vakaru Lietuvos, bet ir visos valstybès mastu. Žemiausios reikšmès teko ir labiausiai nuo Lietuvos vidurkiniu reikšmių (t. y. periferiškiausi) Klaipėdos apskrityje atsilieka Skuodo ir Šilutės rajonai. Statistiniai duomenys pabrèžia vis didèjančias regione socialines ir demografines problemas, kurioms spręsti turi būti imtasi atitinkamų priemonių. Šie pasienyje išsidèstę regionai yra labiausiai nutolę nuo centro, todèl viena iš išeičių šiems regionams būtų užmegzti santykius su kaimyninès valstybės pasienio regionu.

Taigi galima konstatuoti, kad Klaipėdos regionas yra tinkama erdvė bendradarbiavimo santykiams kurti ir plètoti, turinti tiek socioekonominio, tiek demografinio potencialo. Tačiau iškyla diskusinis klausimas, i kurį vienareikšmiško atsakymo nėra: kaip reikètų bendradarbiauti Vakarų Lietuvoje, kad būtų naudinga visoms bendradarbiaujančioms valstybėms, kartu būtų bandoma išspręsti vis aštrėjančias problemas, su kuriomis susiduria Klaipedos apskrities rajonai? Ar bendradarbiauti turètų tik centrai, eliminuojant silpnus, merdèjančius regionus, ar didesnis dėmesys galètų būti skirtas būtent periferiniams regionams? Taigi yra keletas scenarijų, kuria linkme reikètų plètoti bendradarbiavimą, tik savivaldybių vadovams ir pačioms bendradarbiaujančioms struktūroms reikètų apsispręsti, kurị iš tų scenarijų pasirinkti.

PAGRINDINIAI ŽODŽIAI: Klaipédos apskritis, centras ir periferija, periferinis regionas, bendradarbiavimas.

JEL KLASIFIKACIJA: R100 